\title{
Viral Particles per Dose
}

National Cancer Institute

\section{Source}

National Cancer Institute. Viral Particles per Dose. NCI Thesaurus. Code C124473.

A unit for virus amount expressed as the number of viral particles per dose. 